\title{
Improving Entrepreneurship In Nigeria's Emerging Economy
}

Adewale Onifade, Moshood Abiola Polytechnic, Nigeria

\begin{abstract}
Employment is a cure for unemployment and its attendant vices like armed robbery, corruption, forgery, internet fraud, and drug trafficking. An "idle mind is the devil's workshop", so says a popular adage. There is increasing unemployment due to too much emphasis on liberal education devoid of vocational and entrepreneurship education and increasing population. Although Nigerian governments try to promote entrepreneurship by making policies regarding funding of businesses, providing enabling infrastructure, implementation of the policies is nothing to write home about because corruption has led to the abandonment of contracts on electricity supply and means of transportation. If the government is to achieve its dream of making Nigeria one of the 20 greatest economies of the world, it should improve electricity, road and railway transportation systems, security, and reduce the cost of communication and entrepreneurship development which is newly introduced at all levels of its educational system.
\end{abstract}

Keywords: Business, Communication, Entrepreneurship, Entrepreneur, Feasibility study, Information, Small business and Technology

\section{INTRODUCTION}

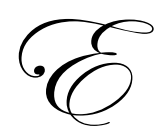

ntrepreneurship is ownership of business whether small- or large-scale. This article is intended to emphasize self-employment in both small- and large-scale businesses. Therefore, the difference between small-scale business ownership and entrepreneurship is discernible. Entrepreneurship refers to ownership of either small-or large-scale business.

The developed or advanced countries like Japan, United States of America, Germany, and Britain have attained their present economic positions because of their encouragement of self-employment.

Self-employment has contributed to the development of these countries, more than government salaried workers. Entrepreneurship or ownership of businesses can help reduce migration from rural areas to urban cities.

There are five groups of people in the work world: students, applicants, salaried workers, self-employed (entrepreneurs), and the unemployable (under-aged, the sick, and the aged). Nigerian salaried workers are being retired or sacked outright from both government jobs and privately owned organizations for one reason or another.

The Government sacked workers for such reasons as old age, sickness, inefficiency, unwillingness to accept change, indolence, corruption, indiscipline, etc. Private industries, on the other hand - apart from those parameters used by public organizations - fire workers if they do not make a profit. When there is crisis in an organization that results in low profit, or the environment that is external to the organization is preventing it from meeting its target or objective, then something negative must have affected the resources.

When workers are laid off, they become unemployed, therefore constituting nuisance to the public by committing vices and crimes, such as armed robbery, advance fee fraud (419), forgery, drug trafficking, internet fraud, prostitution, printing of fake currencies, etc. Other factors associated with serious unemployment being experienced in Nigeria include increase in population; poverty; closure of industries; lack of adequate infrastructure, such as electricity, potable water, roads, communication facilities; increase in both male and female graduates; too 
much emphasis on liberal education devoid of vocational and self-employment education; and changes in technology, especially the introduction of computers that have now replaced many workers.

Although the Nigerian governments (local, state and federal) have put in place some measures to encourage self-employment in the country, the most important infrastructure - electricity, a good transportation system, potable water, security of lives and properties - provision of funds and researches are not adequate.

This paper will highlight the definition of relevant terms, advantages of entrepreneurship, characteristics/ functions of entrepreneurship, problems of entrepreneurship, challenges in choosing a business to establish, establishing a business, sources of capital, the role of Nigerian government in improving ownership of business, and a conclusion.

\section{DEFINITIONS}

1. Business, according to the American Heritage Dictionary (1980), refers to occupation, work or trade in which a person is engaged. Everard and Shilt $(1979$, p.3) defined business as "an organization that produces or distributes a good or service." The effort of people to produce and distribute the goods and services that are requisite for their well-being, comfort, safety, and happiness, and which are of benefit to society as a whole, are what (Glos and Baker, 1967, p.3) called business.

2. Communication, as defined by Little (1974), is the "process by which information is passed between individuals or organizations by means of previously agreed symbols (p.3).

3. Entrepreneur, according to the Oxford Dictionary of Business (2002), is "an individual who undertakes the task of supplying a good or service to the market for profit". Entrepreneurs will usually invest their own capital in a business and take on the risks associated with that investment. The view of capitalism is that the initiative of entrepreneurs creates a society of wealth and that governments should establish conditions in which the activities are encouraged.

In defining an entrepreneur, the points to note and include are:

- that a person is involved (man or woman, young or old)

- he has an idea about a business

- he invest in the business by employing resources

- he takes a risk

- he organizes resources - man, money, machine, materials, methods and morale

- he plans and makes decisions on what to produce, who to employ, where to produce, how to get capital, etc.

- he solves problems - human and non-human

- he wants to make a profit

- he must be diligent, self-reliant, disciplined, innovative, and creative

Onifade (2002. p. 133)

4. Entrepreneurship: There is no one single definition of entrepreneurship, but there are common ingredients in all definitions of the term. According to Di-masi (2008), the earliest definition of entrepreneurship dating back to the 18th century is "the process of bearing the risk of buying at certain prices and selling at uncertain prices." He pointed out that commentators later broadened the definition by adding the concepts of factors of production. He said that early in this century, the concept of innovation in process, market, product and factor was added.

Onifade (2004), defined entrepreneurship as "the act of floating, investing in and managing a business for self-employment and with-profit motive."

"Entrepreneurship is the dynamic process of creating incremental wealth by individuals/groups through the use of researches. Entrepreneurship is an act of initiative, drive, commitment, diligence, perseverance, organized effort... to make some specific functions of performing production activities."

(http:/en.wikipedia.org/wiki/entrepreneurship) 
5. Feasibility study is defined in the Oxford Dictionary of Business (2002) as "an investigation to determine which of a range of decisions is likely to give a satisfactory return in a financial appraisal or economic appraisal of the alternatives."

6. Information, like many other words, has many varied meanings. Webster New World Dictionary (1980) defined it as "knowledge acquired in any manner...facts, data, learning, lore."

Nwankwo (1985) said that information can mean interrelated or structured data, including collection, storage, processing and dissemination of news, data, facts, messages, opinions, and comments required in order to react knowledgeably, as well as to be in position to take appropriate decisions.

Sanders (1983) pointed out that information has attributes of a physical resource, like such resources as manpower, money and materials. These characteristics of information are as follows:

- has value like money, raw materials or manpower

- is measurable in terms of use, life and effects on other resources

- can be valued in terms of collecting, storing, retrieving

- can be budgeted and controlled

- can be related in terms of cost and use value to management objectives

7. Small business: The definition of small business varies from country to country, author to author, and from one time to another. The definition of small business, however, is based on some parameters or factors stated below:

- ownership (one individual or several individuals)

- amount of capital that is invested

- nature of the business (industrial, commercial, services)

- degree of risk involved

- size of the business in terms of number of people employed

- quantity of production (small or large)

- the extent of the market (local, national, international).

- government policy. Government may categorize businesses into small-scale, medium-scale, and largescale using some criteria.

- technology - manual, mechanical, electrical, electronic methods of operating machines and the type of machines

- legality - Armed robbery and drug trafficking are profit-making but are destructive businesses.

(Onifade. 2004. p.124)

8. Technology: The American Heritage Dictionary (1980) defines technology as "the application of science, especially to industrial or commercial objectives". It can also refer to the entire body of methods and materials used to achieve such objectives.

\section{ADVANTAGES OF ENTREPRENEURSHIP}

Some of the advantages of entrepreneurship are as follows:

1. Quality of life/standard of living: A self-employed person is sure of an income and financial gain. Entrepreneurship provides self-employment and income generation. People can own their own houses and cars when self-employed. They will be able to eat good food and solve health problems.

2. Employment: It also creates employment for others.

3. Talents are developed: I am always amazed when I watch musicians and actors on stage. The musicians, actors, and artists develop their talent to entertain their audience for money.

4. Healthy competition: Competition promotes better, quality and standard services. It is common to see people copying successful businesses. Examples abound in our society. We can see these in the establishment of educational institutions, churches, petrol stations, rental businesses, pure water businesses, etc. 
5. Boosting of ego and dignity: There is pride in being an employer rather than an employee. Every person would prefer independence rather than dependence on others.

6. Increase in goods and services: There is no doubt that entrepreneurship will help to increase goods and services and the market in general.

7. Reduction in crimes and vices: "An idle mind is the devil's workshop" is a common adage. Joblessness leads to such vices, such as armed robbery, prostitution, assassination, advanced fee fraud (419), etc. If the miscreants in our society are gainfully employed, there will not be street begging, prostitution and armed robbery; or if we have these vices, they will not be so enormous.

8. Tax Payment: Businesses are expected to pay taxes to the government and likewise their employees, which helps the government in providing infrastructural facilities for the citizens.

9. Experience and Training: Business owners and their employees acquire experience and training in production and administrative activities. Increase in knowledge helps to improve quality of goods and services.

10. Interaction: If it is a small business, the owner is closer to the workers and customers.

11. Flexibility: It is easy to make decisions and changes with respect to the business.

\section{CHARACTERISTICS/FUNCTIONS OF ENTREPRENEUR}

1. Provider of business resources: Capital, labor, land, machines, materials, and information are some of the resources needed.

2. Manager: He carries out the management functions of planning, organizing, staffing, commanding, coordinating, and controlling.

3. Risk bearer: He knows the different types of risk and insurance policies. He should know the difference between insurable and uninsurable risks. He should insure against some business risks.

4. Time and change manager: Time is money if wisely spent. The entrepreneur should be time-conscious. He should be dynamic and willing to accept change where necessary.

5. Marketer: The entrepreneur markets his business of producing products and providing services. He should know pricing policies and advertising methods. He should carry out market and marketing research.

6. Initiator: He initiates and generates ideas. He is creative. He should be able to use his talents and endowment for his benefit and that of society.

7. Motivator/Leader: A leader should be humane. He carries people along in his endeavor. He encourages participation in the decisions affecting the workers and the business.

8. Visionary: The entrepreneur must establish both vision and mission for the business. The vision and mission will be his driving force to achieve his objective.

9. Employer: The entrepreneur is an employer. He creates employment, thus helps to solve problems of vices in society, such as armed robbery, stealing, prostitution, etc.

10. Effective communicator: Effective communication is very essential in business. The entrepreneur should be an effective communicator, not only with his staff, but with the public in general.

\section{PROBLEMS OF ENTREPRENEUR}

Entrepreneur may not be successful in his business because of the following:

1. Lack of Knowledge: Knowledge is the bedrock or basics of any business success. If the entrepreneur does not acquire adequate knowledge through reading, traveling and interacting with experienced people in the same type of business, he may have problems.

2. Lack of change: Business is dynamic and not static. If the entrepreneur does not accept change with regard to customers' taste, he may lose his customers to competitors.

3. Employees' motivation: Employees can "make or mar" your business. Motivate your employees in many ways. You need their loyalty to succeed in your business. Educate and train them in all matters of the business.

4. Lack of consistency and persistency: Many entrepreneurs start and drop a business that does not gain fast. This should not be the case. Learn to persist and be consistent. 
5. Lack of accountability: Most entrepreneurs fail because they do not keep records of sales and purchases. They do not keep inventory and do not ascertain their profits.

6. Risk taking: The business may lead to a slump and doom which may affect the health of the entrepreneur adversely.

7. Inexperience: A neophyte in the business may make mistakes during the early months. He is also vulnerable to antics of fraudulent workers, cheaters, and dubious customers who may play upon his ignorance to exploit him in one way or the other.

8. Inadequate Capital: The amount of capital available for investment will determine, to some extent, the success of the business. If the entrepreneur spends his capital, the business may flop.

9. Unlimited Liability: If the business owner encounters an unforeseen problem that affects the business negatively, he will be the only person to bear the loss. If, for example, you have a large consignment of a product - like kerosene - or as a speculator, you take a risk of hoarding a particular product; and because there is general increase in price and inflation, the government imports the products in abundance and you may have to sell the product at a loss.

10. Human problems: There are human problems in all dimensions. Most employees are dishonest and fraudulent. Human beings can "make or mar" businesses. Many businesses have flopped because of the workers fraudulent practices.

11. Credit facilities: Because of the smallness of the business, the entrepreneur does not enjoy the economy of large scale buying, such as discount and other credits.

12. Health problem: The business owner spends several hours at his work in order to satisfy his customers. He wakes up very early and sleeps late. This may be dangerous to his health.

13. Poor management: Because of inadequate information and inexperience of the entrepreneur, mismanagement of resources may affect the business negatively.

\section{CHALLENGES IN CHOOSING A BUSINESS TO ESTABLISH}

There is proliferation of small businesses in Nigeria that are owned by public servants, artisans, house wives, unskilled people and old people (men and women), but not all of them make a profit. Some may own these businesses as a pastime to while away the time. Any business that does not sustain ones' livelihood amounts to a waste of resources (money, time, effort).

In light of the above, therefore, business owners should ensure that they make a profit by knowing the challenges militating against their business success with a view to overcoming them. Some of these challenges are explained below.

- Information: The importance of information in any business cannot be overstressed. Information about challenges in price or goods and services by manufacturers, government and competitors, availability of commodities; for example, sellers of cement, kerosene and some food-stuff, experience regular changes in the price of these products.

- Personnel: Personnel constitute the most important and most difficult resource in any business. Many workers are very fraudulent, dishonest, deceitful, lazy, unskilled, and disloyal. Since they are a necessary evil, there is the constraint of knowing who is efficient and honest.

- Market: Businesses are vulnerable to market fluctuations resulting from competition, consumers' bias, government policies, and poor advertising strategies.

- Infrastructure: Nigeria's infrastructural facilities needed for business growth are nothing to write home about. In the last three years, there has been improvement in telecommunication facilities that aid communication tremendously, but they are expensive. The country is lacking in the most important infrastructure - electricity. Many businesses have shut down due to expenses incurred on diesel and generating sets. The transportation system is terrible. Railway transport is almost non-existent. Roads are very bad. The air transport flight is prohibitive. Social and physical infrastructure are desideration.

- Management: The business owners do not keep records. A recent survey done by Onifade showed that a very insignificant number of them keep records or daily transactions. Many of them are semi illiterates who do not know how to keep records, though they agreed that keeping records is good. Most of those who keep 
records are those found in pharmaceutical stores. Those in grocery, stationery shops and restaurants did not keep anything. A good business should be able to ascertain its profit or loss periodically.

- $\quad$ Fund: Only very few businesses can start up without some money and other assets. The amount of capital an investor has will determine the nature and extent of business to embark on. In Nigeria, the high interest rate does not encourage borrowing.

- $\quad$ Economic and social vices: Security is very important for the survival of any business. Corruption, armed robbery and fraud threaten survival of any business. The security agencies have not been able to do away with these vices.

If a business is to record success the above problems must be tackled by both the government and business owners.

\section{ESTABLISHING A BUSINESS}

While being a business person is a thing of joy, establishment of a business may make one wealthy; and if care is not taken, it may destroy one forever. Apart from ensuring that obstacles pertaining to the business success are overcome, a business person should establish a business in which he has the experience, training, talent, skill, capital, time, information and other tangible and intangible resources.

There are many businesses that are open to you. Businesses can be classified as Primary (industrial), secondary (commercial), and tertiary (services - direct and indirect).

Before you can start a business on a firm footing, there are many requirements that you have to take into consideration. You may have to answer the following questions: What is my goal? How do I reach that goal? What decisions should I make? What product or service should I produce or provide? Who is to employ? Who needs the product or service? Where do I produce or provide? How much do I need to start it? Where do I get the capital? What is the price to charge? Who do I sell to and who do I buy from? What form of advertising do I use? How do I go about accountability (profit determination, inventory/stock management)? Have I achieved my goal (appraisal and controlling)? Where and how do I get information? What are my priorities? There is need for a feasibility study that will help answer all the questions stated above.

The major or primary objective of any business is to make a profit. In order to achieve these objectives, there is need for proper and adequate planning, which involves decision-making.

When you have commenced the business, there is need to determine your regular customers and how to keep them. Human and public relations are essential for successful businesses. Try to establish goodwill through special services for your customers. Try to keep costs low and always be honest with any person you interact with in the course of doing business. Ensure quality and standard goods and services.

Learn to be consistent and persistent with any business and remember that "Rome was not built in a day". Identify problems and find solutions for them. Learn to foresee obstacles and try to prevent or minimize them.

Three types of businesses have been identified; namely, primary (industrial), secondary (commercial) and tertiary (services - direct and indirect).

1. Primary or Industrial Businesses: There are three classes of industries; i.e. extractive, manufacturing and construction.

Some businesses that can be engaged under each of the three headings are as follows: 


\section{Extractive Industry}

Some businesses in this category are fish farming, oil mining, snail farming, lumbering, bee farming, keeping piggery or poultry, running saw mill, crop farming, tree farming, selling fruits, grocery, animal husbandry, etc.

\section{Manufacturing Industry}

Some businesses in this category include manufacturing of plastic and aluminium plates, bowls, and spoons; weaving; canning; and manufacturing of chalk, bolts and nuts, tiles, glass, bottle, asbestos, plastic containers, office supplies, etc.

\section{Construction Industry}

Small-scale occupations under this heading include building houses, roads, bridges; brick laying; welding; and blacksmithing.

2. Secondary or Commercial Businesses: Commercial businesses are concerned with all activities that facilitate effective and efficient distribution of goods and services. These involve trade (buying and selling) and are found in the following businesses: grocery, supermarket, buying and selling fruits, pure water business, selling cement, ice block production, kerosene business, sale of food stuff, etc. and aid to trades (banking, transportation, insurance, warehousing, advertising, communication and tourism). Some examples are ownership of hotels, guest houses, amusement parks, micro-finance houses, banks, cold storage, insurance firms, telecommunication firms, advertising firms, tourist centres, transport businesses, cooperative societies, and daily contribution.

3. Tertiary Businesses or Services are divided into two categories; i.e. direct and indirect services. The entrepreneur has no business in the indirect services because they are provided by the government at all levels. However, the direct services are those provided by the entrepreneur for his livelihood for which the consumers of the businesses are paid.

Some direct services are found in tailoring, barbering, dry cleaning, laundry, plumbing work, vulcanizing, automobile service and repairs, waste disposal, coaching and teaching classes, healthcare clinics, pharmacy store, hospitals, old people homes, entertaining and musical business, drama groups, educational institutions at primary, secondary and tertiary levels, where church owners earn money for their livelihood, rental services, etc.

\section{SOURCES OF CAPITAL}

There are two major sources of capital or funds: (a) internal and (b) external.

\section{Internal Sources of Finance}

- Personal Savings constitutes a source of finance for the establishment, expansion or diversification of business.

- Ploughed back profit: The profit a business makes that may be retained for the expansion of the business.

- Provisions for doubtful or bad debts, depreciation and tax: These provisions can be used for the business, pending their true determination. They also help to reduce profit on which taxes will be paid.

- Contribution: This means that two or more people may decide to make periodic contributions and members, in turn, take the contribution. This lump sum may be a good source of finance.

- Sale of business property or rights: Business property or patent rights may be sold as a source of funds.

- Will: A will is bequeathed to family members of the deceased and may be used to start a business. The property may be an existing business.

- Gratuity: Retired workers are paid a gratuity that may be used to establish a business. 


\section{External Sources of Finance}

Today, internal sources of finance can never be adequate for any serious business. The major external sources of finance are in the form of loans, which include the following:

- Shares/bonds: Public limited companies can offer shares to the public while private limited companies can issue shares to the people who establish the company. The sale of shares is to increase the capital of the company.

- Overdraft and loans from bank, insurance and other financial houses: Business organizations can borrow money from financial houses, such as commercial and development banks, insurance houses, etc. and is considered short-term finance.

- Cooperative Thrift and Credit Societies: After some months of membership and savings with cooperative societies, a member may take some loans.

- Debentures: Debenture holders are not shareholders, but rather creditors of companies. They are paid a fixed rate of interest whether or not a profit is made. They are considered long-term finance.

- Trade Credit: Trade credit can be used by both large and small businesses. In the olden days, the business practice was tagged 'cash and carry' whereas today it is called 'credit and carry'. Trade credit exists when either, by formal or informal agreement, a seller sells products to a buyer on credit, allowing him a period of time before payment is made. The time between buying and paying is referred to as the credit period. The seller is the creditor. The credit is also called "open book trading".

- Factoring: There are goods and debts factoring. Debt factoring helps to finance a house, called a factor. When a seller (creditor) sells goods on credit to a buyer (debtor), the factor will help the seller (creditor) by paying him a percentage of what the buyer (debtor) owes. It is the responsibility of the factor to collect the debt from the buyer (debtor). It is simply a way of making money available to a seller instead of waiting a long time for the debt will be paid by the buyer.

- Leasing: Instead of a company waiting until it can purchase an expensive piece of machinery before it commences business, it can decide to lease from a company (lessor) that rents it out. The company that rents is a lessee. The lessee pays a charge for this service.

- Hire Purchase is similar to leasing. The ultimate objective is ownership, which makes it different from leasing. Hire purchase is characterized by possessing property on the payment of an initial deposit and an agreement to pay the balance in instalments. It is a source of finance because the business is able to use what it could not pay for at once.

- Dividends and share certificates: You can use your dividends from companies and also sell your share certificates to establish a business.

\section{THE ROLE OF NIGERIAN GOVERNMENT IN IMPROVING OWNERSHIP OF BUSINESS}

Problems facing entrepreneurship and the entrepreneur have already been highlighted. The role of government in encouraging, promoting and improving entrepreneurship and small business ownership cannot be overstressed. Having also realized the relevance of these businesses in the social and economic development of the nation, it behooves the country to assist entrepreneurs.

Although the government has always formulated policies for small and medium enterprises (SMEs), corruption during implementation has been the problem. For example, recent probes of road and railway contracts and that of electricity have shown the bane in the provision of these infrastructural facilities.

The establishment of the National Economic Reconstruction Fund (NERFUND), National Directorate of Employment (NDE), Nigerian Bank for Commerce and Industry (NBCI), Bank of Industry (BOI), The Nigerian Industrial Development Bank (NIDB), The Nigeria Association of Small Scale Industrialists (NASSI), and Industrial Development Centre (IDC) is a pointer to the fact that efforts are being made to recognize entrepreneurship and to promote it.

The government has also introduced entrepreneurship development in the curriculum at all levels of its educational system - primary, secondary and tertiary. 
The government could be improving entrepreneurship development in the following ways:

- $\quad$ Entrepreneurship development at all levels of our educational system should be monitored by all the stakeholders and relevant government agencies in order to achieve its set goals.

- The government should formulate penalties for contractors who do not execute the contracts on infrastructural facilities, such as roads, railways, electricity, water banks, insurance, etc.

- $\quad$ As much as possible, there should be free tax for some categories of businesses while interest rates on loans should be made affordable rather than intimidating.

- $\quad$ Government should also patronize homemade goods, indigenous contractors and artisans trained in Nigeria.

- $\quad$ Banks should be encouraged to establish branches in rural areas.

\section{CONCLUSION}

Nigeria can achieve its target of becoming one of the 20 greatest and most developed countries in the world by the year 2020 if it is industrialized. It can only be industrialized if entrepreneurship is improved and improvement can only come if its infrastructure - electricity, roads and railway system, communication system, water supply, etc. are developed. Social and economic vices - corruption, armed robbery, advance fee fraud (419), drug trafficking, forgery, etc. - are minimized if they cannot be eradicated. This can be achieved by imposing heavy penalties on culprits or those found culpable. Investment cannot strive in an insecure environment; therefore, security of lives and properties should be paramount in the agenda for becoming a great world power.

Finally, entrepreneurship and investors should be encouraged by ensuring availability of loans with low interest rates. Academic institutions and training centres should be equipped with necessary infrastructure and personnel for training and retraining of the entrepreneurs.

\section{AUTHOR INFORMATION}

Dr Adewale Onifade received his NCE in 1974 from National Technical Teachers College, Akoka, B.Sc in Business Education ( $2^{\text {nd }}$ class upper) in 1978 from the University of Nigeria, Nsukka. He received his master's degree and Ph.D. from Bowling Green State University, Ohio, in 1983 and 1985, respectively. He enjoyed scholarship awards for his post secondary education. He had taught at all levels of educational system. He was a teaching fellow at Bowling Green State University and is a member of local and international professional associations. He has authored many textbooks and journal articles.

\section{REFERENCES}

1. Di-Masi, Paul. (2008). "Defining Entrepreneurship". Tp://www.gdrc.org/icm/micro/define.micro.html

2. Everard, Kenneth E \& Shilt, Bernard A. (1979). Business Principles and Management. Cincinnati: Southwestern Publishing company.

3. Glos, Raymond A. \& Baker, Harold A. (1967). Introduction to Business. Cincinnati: South-western Publishing company.

4. Kolawole, A.F. (1996). "Small Scale Business and the Nigerian Public". Paper presented at Ogun State Public Service Forum. Abeokuta, Ogun State.

5. $\quad$ Guralink, David B. (Ed.). (1980). Webster's Newworld Dictionary. New York: Simon and Schuster.

6. $\quad$ Little, Peter. (1974). Communication in Business. London: Longman Group Limited.

7. Morris, William. (Ed.). (1980). The American Heritage Dictionary of the English Language. Boston: Houghton Mifflin Company.

8. Nwankwo, John I. (1985). Fundamentals of Management Information Systems. Ibadan: Spectrum Books Ltd.

9. Onifade, Adewale. (2004). Small Businesses and Entrepreneurship. Abeokuta: KAPPCO..

10. Pallister, John \& Isaacs, Alan. (Eds.). (2002). Oxford Dictionary of Business. (Third Edition). Oxford: Oxford University Press.

11. Sanders, Donald H. (1985). Computers Today. New York: Magraw - Hill Company.

12. http:/en.wikipedia.org/wiki/entrepreneurship 
NOTES 